Studia Anglica Posnaniensia 48/1, 2013

doi: 10.2478/stap-2013-0004

\title{
TIMON OF ATHENS (1606?) AND TIMON (1602?): RHETORICAL AND RITUALISTIC VIOLENCE
}

\author{
STEVE ORMAN
}

Canterbury Christ Church University, UK

\begin{abstract}
This article seeks to explore representations of theatrical anger in William Shakespeare and Thomas Middleton's Timon of Athens (1606?) and a play written by students from one of the Inns of Court, the Inner Temple, entitled Timon, written and performed at the Inn circa 1602. The article is concerned with two types of violence exhibited in both plays; rhetorical violence and ritualistic violence. Early modern rhetorical violence is self-consciously performative and manipulative compared to ritualistic violence which is unbridled and emasculating; a bodily performance that cannot be controlled via self-regulation. By exploring cultural perceptions of anger, this article attempts to account for the range of violence performed by the two Timons.
\end{abstract}

Keywords: Timon of Athens - violence - drunkenness - Inns of Court - masculinity - Early Modern youth culture

William Shakespeare and Thomas Middleton's Timon of Athens (1606?) is a play steeped in excess. ${ }^{1}$ The titular character in the play is excessively bounteous, excessively reliant on friendship, excessively angry, and perhaps, above all, excessively naive. Thus far, few scholars have analysed the play alongside another Timon-play, the anonymous Timon (1602), written by students of the Inner Temple, one of the Inns of Court in London. It becomes quickly apparent that Timon is also a play that is steeped in many forms of excess and this article is interested in the verbal excesses that both plays exhibit, typically to denote feelings of anger and misanthropy. This article is interested in what I perceive to be the ritualistic and rhetorical violence contained within both plays. What I

1 I agree with John Jowett in assigning the play to Shakespeare and Middleton. 
perceive to be ritualistic violence can be equated to an early modern understanding of violence as stated by Helkiah Crooke in his Microcosmographia: A Description of the Body of Man published in 1616. Crooke writes that "[a]nger, which 'women, children, and weake and cowardly men' experience, is 'a disease of a weake mind which cannot moderate it self but is easily inflamed" (quoted in: Kennedy 2000: 7); it is a form of violence that subconsciously forces the body to react with an aggressive gesture, predominantly physical, without prior conscious cognitive thought. Rhetorical violence, on the other hand, I suggest is a form of anger that appears to construct the speaker as selfconsciously aware of their anger and therefore to deliberately simulate the outpouring of emotion that follows. It is a manipulative anger that is grounded largely in verbal abuse. ${ }^{2}$ However, neither Timon of Athens nor Timon can be safely contained in either category. Like their ever-changing protagonists, both plays exhibit ample instances of rhetorical and ritualistic violence.

I begin this article with an analysis of Early Modern drink culture to explore whether the excessive consumption of alcohol and the resulting effects on the body and discourse of the individual can be equated to moments of rhetorical and ritualistic violence performed during moments of anger. I will discuss two moments in both Timon plays that share similar themes concerned with ritualistic feasting and excessive consumption. It is intriguing that in both plays, the banquet where Timon attacks his flatterers demonstrates a moment where an individual is not in control of his body and both banquets conclude with a descent into misanthropy. This article will briefly investigate whether violence can become gendered in Early Modern England and whether a form of controlled masculine violence becomes a self-inflated rhetorical performance that lacks any real semblance of violence.

Early Modern male aggression was linked to a ritualistic drinking culture that at once defined and eroded one's masculinity. The lack of control that individuals possessed over their bodies as well as the change in how they interacted with other people when drunk in early modern England, equated to a similar lack of verbal and physical control instigated by rage and anger. Elizabeth Foyster usefully summarises this idea. She writes that "[1]earning to exercise bodily self-control was vital to the acquisition of honourable manhood. Drinking tested the limits of that self-control" (Foyster 1999: 40) and further comments that "[b]eing able to hold one's drink and remain convivial was essential ... [f]or if a man became so intoxicated that his behaviour became anti-social, then he risked his manhood. Moralists warned that men who were drunk lost their reason and could slip into a bestial state" (Foyster 1999: 40). Both Timons,

2 I am grateful for the comments of an anonymous reviewer that encouraged me to expand upon this distinction between rhetorical as opposed to ritualistic violence. 
who have been drinking prior to their fits of rage, slip into a state of anger that erodes their masculinity, they do become bestial, losing all self-control. Violently removing his flatterers from the banquet, Timon in the academic play speaks:

The pox goe with them;

And whatsoever the horride sounding sea

Or earthe produces, whatsoe're accursed

Lurks in the house of silent Erebus,

Let it, $\mathrm{O}$, let it all sprawle forth, here.

(Bullough 1966: 329) $)^{3}$

to which his faithful servant Laches responds "Will this fury never be appeas'd?" (Bullough 1966: 329). Timon answers "Never, never it; it will burne for ever" (Bullough 1966: 329). Evidently, this is a moment of excessive anger. Shakespeare and Middleton's Timon at the banquet scene roars after throwing water at the senators:

Live loathed and long,

Most smiling, smooth, detested parasites,

Courteous destroyers, affable wolves, meek bears,

You fools of fortune, trencher-friends, time's flies,

Cap-and-knee slaves, vapours, and minute-jacks!

(Timon of Athens, 1.1.92-96) ${ }^{4}$

This is essentially an emasculating moment that not only leads to hate-fuelled rage but also suggests that both protagonists are slipping into the realms of madness, as the first senator reveals: "He's but a mad lord, and naught but / humours sways him" (Timon of Athens, 1.1.108-109). Anger, madness, and misanthropy are, therefore, invariably linked to cognitive weakness; something which Apemantus had previously suggested when he visited Timon in the woods outside Athens: "This is in thee a nature but infected, / A poor unmanly melancholy" (Timon of Athens, 14.203-204). This suggests that Timon has a diseased brain that has ultimately emasculated his corporeal surface and verbal placidity. A similar episode occurs in the academic play Timon where the protagonist's brain is disturbed by his rage. Laches begs: "Leave of complaints;

3 All references to the anonymous play Timon are from Geoffrey Bullough, Narrative and Dramatic Sources of Shakespeare: Vol. 4. James C. Bulman has edited the complete manuscript of Timon for The Malone Society.

$4 \quad$ All references to Shakespeare and Middleton's Timon of Athens are from John Jowett's edition for The Oxford Shakespeare.

5 Jeremy Tambling (2000: 147) suggests that the play Timon of Athens is steeped in "melancholia and frustrated anger which becomes misanthropy". 
griefe augments misery" to which Timon replies: "I am besides myselfe, I knowe not how" (Bullough 1966: 319) suggesting that the individual has little command over his speech when madness assumes control of the body.

Anger, as a bodily experience, is concomitant to drunkenness. Intriguingly, Thomas Young, the author of the pamphlet Englands Bane: or the Description of Drunkennesse (1617) labels drunken men "monsters of men, which through the loathsome vice of Drunkennesse commit all manner of sinne". He lists these sins as "filthy talke, fornication, wrath, murther, swearing, [and] cursing" (Englands Bane, B1r). Man, when drunk, is transformed into what Young calls "the polluted body of this vgly Monster" (Englands Bane, B1r). Furthermore, it was the transformative capabilities of drinking to excess that troubled Early Modern pamphleteers. Thomas Nashe, like Young, had also commented upon eight types of beastly drunks in his Pierce Penniless his Supplication to the Devil, printed in 1592 (Nashe 1964: 61). ${ }^{6}$ Nashe suggests that drunkenness is an imported vice, commenting on "superfluity in drink: a sin that ever since we have mixed ourselves with the Low Countries is counted honourable, but before we knew their lingering wars was held in the highest degree of hatred that might be" (Nashe 1964: 59). Nashe suggests that there was a time when Englishmen would be ashamed to admit that they held an acquaintance with a drunk-man, let alone suffer themselves to become frequently intoxicated: "Then, if we had seen a man go wallowing in the streets or lien sleeping under the board, we would have spet at him as a toad and called him 'foul drunken swine', and warned all our friends out of his company" (Nashe 1964: 59). Nashe likewise invokes an animalistic vocabulary to insult those men who appear drunk, rendering their bodies into either a toad or a swine.

Thomas Heywood in his pamphlet entitled Philocothonista, or, the Drunkard, Opened, Dissected, and Anatomized (1635) would provide the most extensive commentary on the beastly transformation that men suffer by drinking to excess. A large frontispiece dominates the first page of the pamphlet and strikingly depicts several bodily transformations as a result of drinking to excess. Every 'body' that is depicted in this illustration seated around the table quaffing cups of alcohol, wears contemporary male attire. However, the heads on the male bodies are of the animals that the type of drunkard represents. At the side of the illustration, the hostess looks on disapprovingly. The frontispiece depicts a Dog fighting with an Ass; a Goat swaggers as he drinks from his cup as a Hogg spews on the floor beside him. Heywood's accompanying verse upon the frontispiece critiques those who drink to excess:

6 All quotations from Nashe's Pierce Penniless his Supplication to the Devil are from Thomas Nashe: Selected Works, edited by Stanley Wells. 
Calves, Goates, Swine, Asses, at a Banquet set,

To graspe Health's in their Hooft's, thou seest here met;

Why wonder'st thou oh Drunkard, to behold

Thy brothers? In whose ranke thou art inrowl'd,

When thou (so oft, as tox't at any Feast)

Can'st bee no better held, then such a beast,

Since like Cyrcean Cups, Wine doth surprise

Thy sences, and thy reason stupefies,

Which Foe, would Warre-like Brittaine quite expel,

No Nation like it, could be said to excel.

${\text { (Philocothonista })^{7}}$

Heywood's verse links the animals to their brothers; the fellow male drunkards who are similarly as devoid of reason and sense as the beasts are, before concluding that in the forty years since Nashe's pamphlet, Britain now exceeds all other nations in the sheer quantity of drunks that the country can boast. Heywood's moralistic pamphlet begins by lambasting drunkenness as something that all good men should avoid. "The horrid vice of Drunkennesse and Intemperance, which like the Cup of Cyrces, turnes Men into beasts, is to be avoided, as an open enemy to all goodnesse and vertue" (Philocothonista, 2). Heywood, like Nashe and Young before him, also describes the beastly transformations that men who drink too much alcohol undergo. Heywood's descriptions are designed to warn those visitors to alehouses and taverns to moderate their drinking lest they become subject to a beastly transformation and also to inflict shame on those men who can recognize that their own behaviour corresponds with one of the senseless beasts. Heywood identifies those "Drunken Asses, who beare themselves in their lavish and riotous cups, no otherwise then the Beasts, whose names they deserve as being rude, Ignorant, Infacious, Illnurtered, shamelesse, Ill-tutered, and unmanerly" (Philocothonista, 3).

Some men, such as the 'Dogge-drunk' are so overpowered by drink that they transform into a completely different character compared to how they act when sober. Heywood warns, "and of such ought all men to beware; these like spannells faune upon any man in their better temperature, but when their braines are heated in the blood of the Grape, they will fasten on thee like Mastiffes" (Philocothonista, 3). For some men, drink can turn the mild into the deeply vicious. The exact reverse transformation can also occur in those who are said to be 'Sheepe-drunk'. A 'Sheepe-drunk' is emasculated by drink, losing all of his manly courage and instead becomes governed by womanly passions. They "are said to be sheepishly sottish in their healthing, when wine takes away all manly courage from their hearts, melting them into such Effeminacy ... they will oft times weepe in a kind of superstitious piety, and seeme to be terrified

Text accompanying Frontispiece. 
with the feare of Sprites and Hobgoblins" (Philocothonista, 4). Those that are turned into 'Calve-drunks' or 'Ape-drunks' with excessive drinking become the most bestial and ridiculous type of drunkard, "Such are said to bee drunke like Calves and Apes, who when they begin to bee Cup-shot, and that the Wine or Ale worketh in their heads, can stand upon no ground, but leape and dance, and caper, toy, laugh, sing, and prattle, troubling the whole company with their Antick gesticulations" (Philocothonista, 4-5). Heywood also describes a further type of drunkard, those that are "said to bee drunke as Foxes, and those are they who Insidiate men in their Cups, and urge others, quaffing and healthing for no other purpose then to intrap them in their speeches, and bring them into trouble, or to catch some advantage of their words, thereby to supplant them in their estates, and such may bee call'd Pollitick Drunkards" (Philocothonista, 5). For Heywood, those who are 'Fox-drunk' are one of the most socially deviant types of drunkards, they are doubly-dangerous to the body of the man who cannot control his drink and may be further exploited in the company of one such 'Foxdrunk'. Finally, Heywood is quite explicit in what he perceives to be the most shameful and socially-subversive drunkard:

\begin{abstract}
But above all; These are most ridiculous and nasty, who by giving themselves over to all beastiall vinositie, by spending whole dayes, and consuming night after night in Tavernes, and Tipling-house returne from thence, either led or carried, who oft times stumbling, lie wallowing in the kennels, and so appeare no other than Hoggs or swine, newly come durty and dawbed out of the puddles.
\end{abstract}

(Philocothonista, 6)

Those who are 'Hogg-drunk' are filthily dirty, wasting away their time in impure pursuits and are the furthest removed from any trace of humanity, never mind masculinity, and such a character emphasises the strongest associations between alcohol and the monstrously beastly. Heywood offers a stark warning to his readers, repeating many of the sentiments that were previously expressed by Thomas Young. Heywood writes "Let every bashfull and modest man avoid drunkennesse, for it is a monster with many heads, one of obsceane talke, others of Blasphemy, Prophanation, Lying, Cursing, wrath, Murder, \&c" (Philocothonista, 8$)$. Drunkenness is just one transgression. After a man is intoxicated, further multiple and damning sins will follow that the drunken body has no ability to self-police.

Could the excessive consumption of alcohol function as a catalyst to ritualistic violence? Shakespeare and Middleton's Timon is monstrous after a banquet of excessive consumption, which suggests a parallel between drinking rituals and misanthropic-fuelled madness. ${ }^{8}$ The entire spirit of the play and the rela-

Whilst Shakespeare and Middleton's Timon certainly does not engage in excessive drinking 
tionships within are neatly summarised by Hugh Grady (2009: 239) as "corrosive" and "aggressive". ${ }^{9}$ As Grady (2009: 122) observes, Alcibiades and Flavius both treat Timon's misanthropy as a kind of madness or disease" that cannot be taken seriously and should be pitied. Such ritualistic violence is also present, not only in the academic play Timon, but many members of the primarily student-based audience watching this play in 1602 were also drunk at a time when revelry and ritual dominated the Inns of Court. The intoxicated students undoubtedly fulfilled some of the negative animalistic excesses that would later be commented on by moralists such as Thomas Young. Young himself was a member of Staple Inn, which was attached to Gray's Inn, and no doubt witnessed first-hand the monstrous nature of student drunken excess. Many of the young men watching this academic performance are such individuals who are deemed by society as most vulnerable to the ritualistic drunkenness and unbecoming anger that such times of revelry afforded them. As young men with uncontrollable passions, the audience too, are configured like the protagonist Timon, dangerously unstable and prone to being ruled by moments of anger, rage, and madness. As Alexandra Shepard has revealed, "Lust, drunkenness, anger, and idleness were demonised as particular pitfalls stemming from an incapacity for self-control ... Young men were depicted as 'polluted' with 'the burning lustes of the carnall affections' which, combined with their own surfeit of heat, generated an explosive bodily concoction" (quoting William Guild 2003: 26). It was drink that was the real problem for Early Modern youths. Drunkenness left a man in a similar state to madness. As Shepard comments " $[t]$ he 'artificial heat' of wine 'putteth fire to fire', diminishing a young man's capacity for action by wasting the body's natural heat and overpowering the mind" (quoting Sir Walter Raleigh 2003: 27) and "drunkenness was 'nothing else but a voluntary madness"” (quoted in Keepe within Compasse 2003: 27).

Appearing drunk was to demonstrate a failure to control your body, but anger was constructed as an extreme moment of lack of self-control, a moment when the body was ruled by excess. As the anonymous Office of Christian Parents printed in 1616 reveals, anger was "'unnaturall, uncivill, unreasonable ...

to the same levels that the Inns of Court's Timon does, I think it is worthwhile to stress that the body of Shakespeare and Middleton's Timon is so excessively unstable, that even a small quantity of alcohol causes change in his actions and cognition. A similar moment occurs in Timon where the clown Lollio becomes intoxicated very quickly after a relatively small amount of alcohol has passed his lips in Act 2 Scene 5 (Bullough 1966: 310-312). The same could be said of Cassio in Shakespeare's Othello.

9 The unstable nature of personal relationships is effectively mirrored in the generic instability of Timon of Athens. Robert B. Pierce's stimulating article suggests that "[h]ow one defines tragedy will shape what one attends to in Shakespeare's curious play, and indeed Timon [of Athens] becomes a different text depending on what kind of tragedy one expects to find there" (Pierce 2002: 81). 
base, cowardly, and miserable ... foolish, desperate, and dishonourable" (quoted in Shepard 2003: 27). Becoming angry equates to becoming uncontrollable and monstrous whilst at the same time losing all trace of masculinity, undesirable qualities that we have already seen discussed in the discourse of drunkenness. The end product of anger is an emasculated, mad, uncontrollable, gender-less beast, far removed from humanity. ${ }^{10}$ As William Gouge wrote in $O f$ Domesticall Duties in 1622, anger caused "the heart to swell againe, and as it were fire to come out of the eies, and thunder out of the mouth" (quoted in Shepard 2003: 28). Timon certainly thunders in his verbal violence. Shakespeare and Middleton's Timon is excessively angry to the point where his anger exceeds the conventional understanding of a character who is 'in rage' and seeps into incomprehensible madness. But in every aspect of Timon's character we see excess, as Apemantus observes: "[t]he middle of humanity thou never knowest, / but the extremity of both ends" (Timon of Athens, 14.302-303); Timon is excessively bounteous, excessively angry, and excessively mad, seeming to suggest that it is a fundamental flaw in his very approach to life, something which the first senator, who pleads in vain with Timon to leave the woods and return to Athens, realizes. ${ }^{11}$ The senator comments that "[h]is discontents are unremovably / [c]oupled to nature" (Timon of Athens, 14.759-760); that is, as John Jowett (2004: 315) elaborates, Timon's bad humours are part of his essential character, constantly in flux, irreversible. Timon's loss of self-control is an exquisite dramatic example of how the early modern body is constantly in crisis when subjected to emotional disturbance; what affects the body inside the skin is frequently emitted at a physical surface level; a feeling of inner anger instantly becomes thrust out into a performative gesture or verbal utterance.

Timon himself recognises how fluid bodily humours are early on in the play when he chastises Apemantus' bad 'humour'; 'humour' here signifies his disposition and is invariably linked to humoral theory, which suggests that Apemantus is ruled by melancholy. Timon speaks, "[y]e've got a humour there / Does not become a man; 'tis much to blame. / They say, my lords, Ira furor brevis est, / But yon man is ever angry" (Timon of Athens, 2.26-9). Once again, in Timon's eyes, anger is primarily constructed as a feminine emotion that when experienced by the male body is emasculating. The Latin from Horace which

10 And of course, Timon is unable to relate meaningfully to men or women in the play. He is monstrous in his hermaphroditic self-identity. I am grateful for the comments of the anonymous reader for expanding my understanding of the significance of this moment in the play.

11 Timon's character in the first half of the play was also unnatural in his very nature of excessive gift-giving, just as he is excessively unnatural and unmanly in his misanthropic exile. As William O. Scott (1984: 295) suggests, Timon, in Shakespeare and Middleton's play, "is generous in impulse". The philanthropic nature of the protagonist is not forced; it is essentially a part of his character. 
translates as 'anger is a short madness' eerily foreshadows Timon's own inability to control his humoral body and consequential consummation by a long madness that ends in death. The academic Timon also develops this idea with the protagonist admitting: "my hart doth boyle with hate" (Bullough 1966: 335). It is evident that Timon, in his excessive performances during the play, also constructs friendship in a similarly excessive manner. Tom MacFaul (2007: 142) reads the play as a critique of placing too much importance on friendship and social relationships that reveals the "folly of human optimism". MacFaul (2007: 142) argues that "[a]n over-reliance on friendship puts life out of balance, and tends to produce melancholic or tragic results", revealing that it is the loss of friendship that ultimately produces a despondent, aggressive individual who no longer accepts that society can function without such a bond. Madness is the end product. Such a descent into an ungovernable body that can no longer function in society, because of a broken friendship, ultimately reveals the violent tendencies that a singular existence can inspire for failing to adhere to the social ritual of companionship. It is the loss of friendship and social relations that also dominate the actions of the protagonist from the academic play Timon. Here is another character who descends into madness because of his failure to function in social rituals.

But the academic Timon could be functioning as a piece of rhetorically playful meta-theatre. James Bulman, building on the earlier work of Muriel Bradbrook, reads the play as self-consciously aware of traditional Christmas festivities that took place at the Inns of Court. "At Christmastime the barristers of each Inn would appoint their own royalty - often a Prince of Misrule and his attendant courtiers - to hold court until Candlemas. It was the duty of the Prince to issue edicts (parodies of court rhetoric), make state visits to other Inns, host banquets and provide dramatic entertainments" (Bulman 1974: 114). This is not unlike the court of Timon. Shepard has commented on a conflict between students of Trinity and St John's colleges at the performance of an academic play in Oxford in 1611 as further evidence that student performances were places of revelry and an opportunity to appear 'manly' in fighting for the college that the student belonged to. Shepard comments on the evident "rowdiness at college plays" by describing the 1611 fracas which began when "a Johnian playgoer was struck with a torch by a Trinity stage-keeper, and ended only after several St John's members had been pelted with stones from the Trinity Great Gate and the battlements on the wall behind Trinity's chapel had been clubbed to pieces" (Shepard 2003: 106). Shepard also records that "[s]tones and water had been collected as ammunition as much as two weeks in advance of the riot" (Shepard 2003: 106-107). It is interesting that stones and water were the offensive weapons, much like the instruments of anger in both Timon plays but above all this example is intriguing because here is a violent riot that lacked anger. Due to the 
nature of the planned event, the 'drama' unfolds like a scene from a play and Shepard confirms that this riot is an opportunity for the students to prove their courage and bravery to fellow peers rather than a virulent rage fuelled display of territorial dominance (Shepard 2003: 107). This instance credits the young students as 'manly' men instead of eroding their masculinity, unlike both of our theatrical protagonists whose rage strips them of reason. So if, seemingly ireless revelry dominates student plays, could the academic Timon merely present the audience with a form of violence that is consciously playful and simply rhetorical? ${ }^{12}$

As Bulman suggests, the protagonist of Timon from the Inner Temple play conforms to this notion of a Prince of Misrule, surrounded by revellers and hosting lavish banquets for his fellows. Bulman (1974: 116) writes: "[t]he primary purpose of a Christmas Prince was to organize banquets. The menus often were sumptuous; and it is not surprising that a great percentage of a prince's revenue was spent on food". The devouring of the Christmas Prince equates to Timon's flatterers literally devouring him of his generosity, good-nature, and revelling spirit. Timon's anger in the academic play may well inspire moments of laughter in the audience watching the performance during a time of revelry, but the anger showcases and "satirizes rather scathingly the ungenerous nature of many participants in the revels" (Bulman 1974: 117). Laughter may well be the audience's response when the character Gelasimus provides the wrong response to Timon's madness: "Ha, ha, he! / How melancholy walkes hee to and fro!" (Bullough 1966: 319) and laughter is coupled to one of the final actions in the play when Gelasimus pleads: "Sweete Timon, / Breake thou my heade with one small piece of gold" (Bullough 1966: 338) before Laches wallops him over the head with his spade. The ending of the play would seem to suggest that an audience has experienced shallow violence in this academic play. In the Epilogue, Timon speaks: "What's this? I feele throughout / A sodeine change; my fury doth abate, / My hearte growes milde, and laies aside its hate" (Bullough 1966: 339). It is a problematic moment that immediately erases the aggressive and misanthropic violence that has engulfed Timon throughout the latter stages of the play. Left alone, Timon in a moment of self-conscious self-control, regains his capacity to reason and leaves his naturally beastly anger behind. ${ }^{13}$ It is

12 I am grateful for the comments of the anonymous reviewer who suggested that there may be a link between militaristic violence and student violence. Unfortunately, lack of space prohibits a discussion here, but militaristic violence performed in its set sphere in society is certainly comparable to drunken student violence at the Inns of Court. Alcibiades, himself a military man, defends a soldier who was not "drunk with rage" (Jowett 2004: 246), see scene 10.20-23.

13 It is important, of course, that when left alone on the outskirts of Athens, Shakespeare and Middleton's Timon undergoes no such bodily-reversal into a self-reasoning being. I am 
almost as if the state of isolation has allowed for self-reflection and rejection of his rage. Without an on-stage audience, a rhetorical outpouring of emotion falls on deaf ears and it is fitting that the flatterer Demeas labels Timon "easily the Prince of Rhetorick" (Bullough 1966: 337).

Violence certainly gains a performative element in this academic play which functions most appropriately where multiple characters can witness such anger. Timon's rhetoric constantly turns towards declarations of physical violence to those who are within his grasp, and the hyperbolic nature of Timon's rhetorical violence opposes the shared ritual of underlying aggression that is apparent in the scenes of drunken camaraderie in the play: ${ }^{14}$

Eternall darkness ceaze upon the day!
Ye Starres, goe backeward! and a fearfull fire
Burne up the Articke and Antarticke Pole!
Noe age, noe country yeelds a faithfull friende.
A cursed furie overflowes my breast.
I will consume this Cittie into dust
And ashes... I am to mischiefe bente:
These naked hands wante but some instrumente.

(Bullough 1966: 324)

Timon's rage is levelled at society, akin to Shakespeare and Middleton's Timon as Grady (2009: 106) comments, "[n]owehere, however, is the tone of a Shakespearean play more bitter or caustic in its denunciations of the deleterious effects on society of the money economy than in Timon [of Athens] ${ }^{15}$ Even Timon's gift-giving is aggressive as Coppélia Kahn has noted that Timon is encapsulated in a world of competition and mutual aggression that can be interpreted as "unconscious aggression" (Grady 2009: 112). The very fact that it is unconscious aggression that acts as a prelude to Timon's misanthropy, suggests that both Timon's gift-giving and latter misanthropy are, to some extent, simulated and as fake as the friendships that Timon literally purchases in the early parts of the play. Grady also believes that Timon has created an illusion of reality. Grady writes that Timon "lives in a self-created, counter-factual world based on the denial of the real but projecting an imagined reality ethically superior to the real - a non-capitalist realm where wealth is freely available to meet human needs and to create gratuitous aesthetic pleasures" (Grady 2009: 113).

grateful for the comments of an anonymous reviewer with regards to this matter.

14 See Bullough (1966: 310-312).

15 It is also important that Anthony B. Dawson and Gretchen E. Minton in their Arden edition of the play suggest that Timon is an "attractive figure in his vehemence" (Dawson and Minton 2008: 45), further exemplifying the performative nature of Timon's theatrical anger to instil moments of affinity in the audience. 
With his bought and excessively fake false-friendships, then Timon can only expect excessive anger to be the lifetime warranty on his purchase. If falsefriendship can be created so elaborately and simulated so deliberately, could Timon's anger also be mere simulation, a self-conscious rhetorical performance that lacks violence?

Apemantus threateningly posits such an idea to Timon in the woods: "Men report / Thou dost affect my manners, and dost use them ... Do not assume my likeness" (Timon of Athens, 14.199-200, 219) before suggesting that Timon's violence is simply rhetorical, fake: "If thou didst put this sour cold habit on / To castigate thy pride, 'twere well; but thou / Dost it enforcedly" (Timon of Athens, 14.240-2). Their conversation slips into an insult-flinging contest that Grady observes ultimately lacks violence, becoming "darkly comic" (Grady 2009: 121). "The alienation of each man from his society finally transforms a philosophical debate into a schoolboys' mutual taunting contest" (Grady 2009: 121). Violence becomes boyed and rather childish, a rhetorical slug-fest that reveals how uncontrollable the body of Timon has become. And that boy-ed violence becomes incomprehensible to the audience as an aggressive act because we feel pity for Timon, due to what Grady (2009: 122) calls "the absurdity of his own blanket condemnations". The rhetorical flourishing strips away the violence of Timon's words, but, crucially, Timon's suicide will provide a rhetorical death that again contains much more art than it does violence, as Grady (2009: 127-128) has observed, the epitaphs "aestheticiz[e] his hate and leave it as a last gift".

It is important to remember that Early Modern women were especially creative in their anger. As Bernard Capp (2003: 70) has suggested: "Women as well as men recognized sexual insults as by far the most effective weapon against other women, even in quarrels about wholly different issues". Creative verbal violence often focused on the sexual violence of such heated exchanges and Laura Gowing has listed some of the choice and creative insults that early modern individuals slung at each other: From church court records we have 'maggottie whore', 'pockey lousey hedge whore', 'gouty legged whore' and 'scurvie fatt arst quean' (Gowing 1998: 66-7). All are highly sexualised and aggressive, and, crucially, all of the insults were spoken by women to women. What is interesting here is that verbal violence becomes excessively rhetorical, much like in the case of Shakespeare and Middleton's Timon, who not only vocalises linguistic excess in a fashion similar to the sexual slander that Early Modern women resorted to, but Timon also risks transformation into a feminine body. Timon risks losing his self-mastery that defined his masculinity and fluctuating between a masculine and feminine body, epitomises the monstrous body of the drunkard ruled by passion and devoid of human qualities. As Jowett (2004: 26) crucially observes, Timon "becomes angrily eloquent in response to his selfinflicted misfortune" and whilst rhetorical violence may sound particularly 
menacing, the potential for Timon to actively instigate such destructive invocations is erased. "Matrons, turn incontinent! / Obedience fail in children! Slaves and fools / Pluck the grave wrinkled senate from the bench / And minister in their steads!" (Timon of Athens, 12.3-6). Jowett (2004: 27) comments that Timon's speech, which expresses loss rather than authority, "require[s] the human voice to become an instrument that is outrageously expressive". ${ }^{16}$ Timon's rhetorical violence is just that, a verbal outpouring of emotion that is selfdestructive rather than posing any form of threat to disrupting societal functioning. ${ }^{17}$ The academic Timon is certainly more disruptive to society in the protagonists' ritualistic violence, Timon even manages to convince Laches to join him and perform accordingly to his ritualistic cult: "If thou command, my parents I'le despise, / Thou so commauanding, will them ever hate" (Bullough 1966: 330) and both together wish destruction on society: "LACH: Lett seas of bloudshedd overflow the Earth! / TIM: Men, woemen, children perish by the sword! LACH: Lett funeral follow funeral, and noe parte / Of this world ruyne want!" (Bullough 1966: 331).

As I hope this article has tentatively demonstrated, the rhetorical and the ritualistic appear to be intertwined in any act of aggression, whether verbal or physical. Both plays contain moments of ritualistic aggression that is always invariably linked to a social ritual of excessive consumption, typically drinking and eating. In the case of Shakespeare and Middleton's Timon it is fitting that such participation in social rituals of consumption contribute to the protagonists' misanthropy. The same is also true of the academic play Timon. There is much work to be done on the relationship between the excessive consumption of food and alcohol in relation to physical violence but I think it is fitting to conclude this brief investigation with a couple of questions; what does lie beneath the surface of the physical body when a character is performing anger? Are all violent verbal performances rhetorical and ritualistic and reflective of the drunken body? Perhaps Shakespeare's Timon provides the final word on the

16 Darryl Chalk perceives such a moment to reveal the conflict within the body of Timon. Chalk (2009: 3) writes that, "[a]fter his precipitous change, Timon spends the second half of the play in a kind of disease-induced frenzy, an impassioned delirium of fury, ranting some of the most vitriolic speeches in all of Shakespeare. Timon's metamorphosis divides the play into two seemingly irreconcilable halves and often leads critics to dismiss it as fragmentary, psychologically incoherent, and possibly even unfinished. Yet this radical emotional shift is not merely psychological - it is also physical, repeatedly rendered in the language of the play as an external manifestation of changes happening inside Timon's body". Such dissolution of Timon's 'old body' once fully immersed in misanthropy invariably creates a new body that appears excessively rhetorical in violence.

17 See William O. Scott's article which also analyses the idea that Timon "is remarkably ineffectual in his efforts to buy the enactment of his curses of general destruction and selfdestruction" (Scott 1984: 298). 
decay of the cerebral and the physical surface of the body: "[h]is semblance, yea, himself, Timon disdains" (Timon of Athens, 14.22); a finite misanthropic destruction of the 'self'.

\section{REFERENCES}

\section{PRIMARY SOURCES}

\section{Anonymous}

1616 Keepe within compasse; or, the worthy legacy of a wise father to his beloved sonne. London.

1616 The office of Christian parents: Shewing how children are to be governed throughout all ages and times of their Life. Cambridge.

1966 Timon. Narrative and dramatic sources of Shakespeare. Vol. 4 (Edited by Geoffrey Bullough.) London: Routledge and Keegan Paul, 297-339.

1980 Timon. The Malone Society. (Edited by J. C. Bulman and J. M. Nosworthy.) Oxford: Oxford University Press.

Crooke, Helkiah

1616 Microcosmographia: A description of the body of man. London.

Gouge, William

1622 Of domesticall duties. London.

Heywood, Thomas

1635 Philocothonista, or, the drunkard, opened, dissected, and anatomized. London.

Nashe, Thomas

1964 Pierce Penniless his supplication to the devil. Thomas Nashe: Selected works. (Edited by Stanley Wells.) London: Edward Arnold.

Raleigh, Sir Walter

1632 Sir Walter Raleighs instructions to his sonne and posterity. London.

Shakespeare, William and Thomas Middleton

2004 Timon of Athens. The Oxford Shakespeare. (Edited by John Jowett.) Oxford: Oxford University Press.

2008 Timon of Athens. The Arden Shakespeare. (Edited by Anthony B. Dawson and Gretchen E. Minton.) London: Cengage.

Young, Thomas

1617 Englands bane: Or the description of drunkennesse. London. 


\section{SECONDARY SOURCES}

Bulman, James C.

1974 "The date and production of Timon reconsidered", Shakespeare Survey 27: 111-127. Capp, Bernard

2003 When gossips meet: Women, family, and neighbourhood in Early Modern England. Oxford: Oxford University Press.

Chalk, Darryl

2009 "“A nature but infected': Plague and embodied transformation in Timon of Athens", Early Modern Literary Studies 19: 1-28.

Foyster, Elizabeth A.

1999 Manhood in Early Modern England: Honour, sex, and marriage. London: Longman.

Gowing, Laura

1998 Domestic dangers: Women, words, and sex in Early Modern London. Oxford: Oxford University Press.

Grady, Hugh

2009 Shakespeare and impure aesthetics. Cambridge: Cambridge University Press.

Jowett, John

2004 "Introduction" to Shakespeare and Middleton's Timon of Athens. Oxford: Oxford Shakespeare.

Kennedy, Gwynne

2000 Just anger: Representing women's anger in Early Modern England. Carbondale: Southern Illinois University Press.

MacFaul, Tom

2007 Male friendship in Shakespeare and his contemporaries. Cambridge: Cambridge University Press.

Pierce, Robert B.

2002 "Tragedy and Timon of Athens", Comparative Drama 36/1-2: 75-90.

Scott, William O.

1984 “The paradox of Timon's self-cursing”, Shakespeare Quarterly 35/3: 290-304.

Shepard, Alexandra

2003 Meanings of manhood in Early Modern England. Oxford: Oxford University Press.

Tambling, Jeremy

2000 "Hating man in Timon of Athens", Essays in Criticism 50/2: 145-168. 